\section{Ethical Lingua}

Journal of Language Teaching and Literature

ISSN 2355-3448 (Print)

ISSN 2540-9190 (Online)

Volume 5, Number 1, February 2018

pp. $31-38$

\title{
Defining Plagiarism: A Literature Review
}

\author{
Akbar \\ akbarakbar@iainpalopo.co.id \\ Institut Agama Islam Negeri (IAIN) Palopo, Indonesia \\ Received : 09 January 2018; Accepted : 22 January 2018 \\ DOI $\quad$ : https://doi.org/10.30605/ethicallingua.v5i1.750
}

\begin{abstract}
Plagiarism has repeatedly occurred in Indonesia, resulting from focusing on such academic misbehavior as a "central issue" in Indonesian higher education. One of the issues of addressing plagiarism in higher education is that there is a confusion of defining plagiarism. It seems that Indonesian academicians had different perception when defining plagiarism. This article aims at exploring the issue of plagiarism by helping define plagiarism to address confusion among Indonesian academics. This article applies literature review by first finding relevant articles after identifying databases for literature searching. After the collection of required articles for review, the articles were synthesized before presenting the findings. This study has explored the definition of plagiarism in the context of higher education. This research found that plagiarism is defined in the relation of criminal acts. The huge numbers of discursive features used position plagiaristic acts as an illegal deed. This study also found that cultural backgrounds and exposure to plagiarism were influential in defining plagiarism.
\end{abstract}

Keywords: plagiarism; literature review; higher education 


\section{Introduction}

Plagiarism has repeatedly occurred in Indonesia, resulting from focusing on such academic misbehavior as a "central issue" in Indonesian higher education (Adiningrum, 2015, p. 108). Some academicians have expressed frustrations because such academic breach has been embedded in academic culture (Soendjoto, 2013; Sujarwo et al., 2012). Possibly, one of the reasons for this emerging perception is that plagiarism has become "common view" (Sujarwo et al., 2012) that can be identified through academic routines in different educational levels, either in National Final Exam in Primary, Secondary education, or in the academic writing for undergraduate students. Indeed, Pudjiastuti (2012) (as cited in Aryani, 2014) found that academic misconducts (including cheating and plagiarism) in Indonesian education institution occur from primary education to university.

Meanwhile in university level, Aryani (2014) examined the pervasiveness of plagiarism among university students in an Indonesian university. She carried out focus group and survey to find out how serious the issue among university students. The study revealed that $100 \%$ of the university students had plagiarized once and perceived that plagiarism does not include infringement to academic integrity. The General Director of Higher Education of the Republic of Indonesia states that a number of plagiarism may have happened in low quality universities, higher than plagiarism cases in high quality universities (Anam, 2014).

One of the issues of addressing plagiarism in higher education is that there is a confusion of defining plagiarism. It seems that Indonesian academicians had different perception when defining plagiarism. Thus, they have different attitudes of accrediting other works to avoid plagiarism. For example, taking other words or sometimes paragraph seems to be regarded legal as long as the authors are accredited. This citing methods cause the absence of voice in some academic works because very often the works are full of attachment of quotations without showing efforts of giving arguments. In this context, taking other ideas is allowable because it has an emphasis of only in part of "accrediting other works". This indicates that there is a blurring of plagiarism definition that has been differently understood among academicians. Therefore, this research aims at providing a definition of plagiarism resulting from reviewing a number of articles that define plagiarism.

\section{Method}

Finding relevant articles for review was the first stage in the literature review. To find relevant articles, it was important to determine relevant databases to ensure the quality of articles. Thus, two databases had been identified 
specifically for searching plagiarism-related-databases. With the help of faculty of librarian, two databases namely ERIC and EBSCO Host were selected to collect specific articles that can help define plagiarism. Article searching was held by a single keyword 'plagiarism'. This was done in order to specify suggested articles by the databases.

It was important to specifically identify the keyword because the databases contain huge numbers of articles. If the keywords were too broad, the database tended to provide abundance of articles that are time-consuming and exhausting to review. After article collection had been carried out, the contents of the articles were analyzed. It was important to ensure the searched contents more specifically to definition of plagiarism. The contents were then collected for review through the process of paraphrasing and synthesizing the articles.

\section{Discussion}

\section{Defining Plagiarism}

Plagiarism is regarded as academic detrimental practices that can negatively impact academic development in higher education. As a result, academicians endeavor to understand such academic disorder. One of the efforts is to provide clear definition of plagiarism in order that confusions will not emerge at time of policing plagiarism. There are some sources that have been helping provide understanding of defining plagiarism. For example, according to Online Etymology Dictionary (2015), the word plagiarism was derived from the word plagiary (back in 1950s), which means literary theft.

Another cognate of plagiarism was plagiarius that was derived from Latin language. The word used in this language is more extremely negative such as "Kidnapper, seducer, plunderer, one who kidnaps the child or slave of another". Plagiarie is also another cognate of plagiarism that means "to kidnap", while plagium means "kidnapping". From this definition, negative impression of plagiarism remains. The discursive features contain the description of plagiaristic acts that are explicitly defined as similar to criminal acts.

It seems that it endeavors to retain negative meaning derived from the words plagiarism. Perhaps this negative meaning that influences Park (2003) as he defines it as "literacy theft" which refers to the absence of acknowledgement to original authors after taking their ideas or words and is regarded as "stealing". He further identifies this negative act as stealing words or ideas which do not include what are perceived as knowledge in general.

Thus definition may be helpful for academic to identify what plagiarism is and how it took place. There are two main points can be identified from Park's definition. Firstly, the act of plagiarism is not only stealing words but also ideas. Second, plagiarism is regarded as the stealing of a specific knowledge which is 
not commonly known as general knowledge.

Since then Plagiarism defined as literary theft has been agreed notion among some scholars that authored plagiarism who used this term (Frazer, 2014; Ison, 2014). However, it seems that scholars do not entirely agree with only one definition used for plagiarism. This disagreement has taken place due to variation of such academic misconduct such as self-plagiarism (Halupa \& Bolliger, 2013). The notion of self-plagiarism is challenging in term of defining it as literary theft. The idea was challenged in term of the stealing of idea. One of emerging question may emerge as academicians encountering this issue is that "how can academicians steal their own ideas?" Although there is an assumption that dictionary can be used to reach agreement for definition of plagiarism (Akbulut et al., 2008), there seems to be no single agreement of definition regarding to plagiarism among the academicians.

Even among academic educators who frequently involve in studies of plagiarism, plagiarism does not come into a single definition. Bennett, Behrendt \& Boothby (2011) examined how university lecturers perceived plagiarism. The study involved 158 lecturers consisted of different races with 92.2\% Caucasian, 1.9\% Multiethnic, 1.3\% Asian, 1.3\% Hispanic, Native American or Alaskan Native $0.7 \%$. After contributing questionnaires to the selected research participants, the study revealed that the lecturers were still uncertain if recycling self-work is regarded as self-plagiarism.

\section{Challenges of Defining Plagiarism}

Similarly, definition proposed by Park (2003) also encounters challenges for several reasons. Firstly, plagiarism cannot be universally accepted because it is related to cultural context or "culture-specific" (Hu \& Lei, 2012, p. 814). With this idea in mind, one academic context as influence by their academic culture may not assume what other culture claim as plagiarism.

Adiningrum (2015) and Kutieleh (2011) studied university students' awareness regarding to plagiarism. They also examined problems faced by students when encountering plagiarism. 33 Indonesian university students who studied in one Australian University were selected as research participants. With focus group interview method, the study found that cultural background plays a major role in the students' understanding of plagiarism. Interestingly, religion has been viewed to be a culturally influencing to be prone to conduct plagiarism. Religion was regarded as an influencing factor that had undermined critical thinking and creativity. The result of the study suggests that perception of plagiarism can be different as a result of their cultural foundation. The perception of plagiarism can promote different perceived definition of plagiarism.

Secondly, the notion of general knowledge on the definition is still questionable. Kirsch and Bradley (2012, p. 82) contends that it is possible that 
what is perceived as general knowledge by one group does not necessarily mean general for other community of disciplines. This is because on discipline community may be exposed more frequently to one knowledge rather than other communities. In addition, the discrepancy of regarding generality of knowledge is unclear due to the absence of criteria for knowledge to be perceived as general. Thus, instead of accepting parks' definition of plagiarism, plagiarism has been defined with a number of attributes that is likely to come into conclusion (Risquez, O'Dwyer, and Lidweth, 2013).

\section{Defining Plagiarism within Contexts}

Despite the fact that "It is unclear whether such definitional differences are specific to disciplines or institutions" (Jiang, Emmerton, and Mckauge, 2013, p. 370). Definition regarding to plagiarism has been given continuous efforts to be clarified. It is because the clarity of explaining plagiarism should be supported by its context (Larrson \& Hanson, 2013). These contextual influences have been regarded as essential to express the intended meaning. For example, Fraser (2014, p.7) contends that "The act of copying of someone else's work whether or not the original author is aware of the fact". In this definition he discusses the context in digital technology. It is the world where materials such as articles, power point presentations, reports and thesis have been pervasively uploaded with open access to public for download purposes. In this setting, the work of others can easily be taken with "a simple cut-and-paste operation".

In addition, Sutherland-Smith (2010) provides definition of plagiarism with an analogy. He expresses agreement that it is a matter of stealing the words and ideas, and ignorance for accrediting the original authors. He then analogized such academic misconduct as child-kidnap. It seems that he internalizes the context of his personal life with a perception that family is invaluable property that must not be owned by others. Similarly, Larrson (2013) prefers to provide Yeo (2007) definition as he discusses plagiarism that frequently occurs in university students' thesis. This definition seems to make sense in term of its emphasis of acknowledging and referencing for higher education students. It is clear that given definition of plagiarism tends to be used by scholars depending on the contextual settings. Different settings such as technology, social and culture are the influencing factors to express intended meanings to define plagiarism. With this notion in mind it is likely that defining plagiarism will take a long journey ahead to find intended meanings.

\section{Defining Plagiarism within Plagiarism Policies}

Policy document can be a useful reference if discussing the broader context of society. However, defining plagiarism from the perspective of policy statements seems to gain little attention. Scholars tend to contextualize plagiarism into specific scope of problem without involving the voice of plagiarism policy. Whereas, plagiarism policy can help understand the expectation of society and 
the priority of the concerned government more specific to higher education context. Defining the policy in this setting may provide collective belief among academics in higher education. Perhaps, one of the fundamental academic works that discusses how policy statements explain definition of plagiarism is an academic work of McGowan's (2008) that provides terminology of plagiarism definition in policy statement.

From this policy statement, a study should be designed to understand the cultural values and practices within the plagiarism documents. Further research should focus on this topic. Also, this review poses a question to understand the difference between the west and the east in defining plagiarism. The two may have different perception of plagiarism. This domain also calls for further research.

\section{Conclusion}

This study has explored the definition of plagiarism in the context of higher education. This research found that plagiarism is defined in the relation of criminal acts. The huge numbers of discursive features used position plagiaristic acts as an illegal deed. For example, kidnap, theft and stealing were used to represent plagiarism. The use of these selected words also indicates that defining plagiarism was direct and explicit to detrimental behaviors. While the notion of plagiarism was defined commonly similar among the academia, challenges regarding to defining plagiarism caused academia to have different perceptions of defining plagiarism. Cultural background is regarded as an influencing factor of differing perceptions of plagiarism. Also, different academic community can have different level of exposure to the instilling plagiarism as the prioritized issue, resulting on the difference of perceptions of addressing such academic misconduct.

This article proposes that to minimize misperception of plagiarism, defining plagiarism should be based on contextual aspects. However, the different defining plagiarism across discipline results in disagreement in different higher education institutions. Thus, it is to return to policy statement on defining plagiarism as it may represent collective belief among academicians in higher education.

\section{Acknowledgement}

I wrote this article during my master study in 2015 at The University of Adelaide. Thus, I acknowledge The University of Adelaide for providing access to a number of databases through the university library to search needed articles for this work. 


\section{References}

Adiningrum, T. S. (2015). Reviewing Plagiarism: An Input for Indonesian Higher Education. Journal of Academic Ethics, 13(1), 107-120.

Akbulut, Y., Şendağ, S., Birinci, G., Kılıçer, K., Şahin, M. C., \& Odabaşı, H. F. (2008). Exploring the types and reasons of Internet-triggered academic dishonesty among Turkish undergraduate students: Development of Internet-Triggered Academic Dishonesty Scale (ITADS). Computers \& Education, 51(1), 463-473.

Anam, K. (2014). Dirjen Dikti: Suka Menjiplak Tanda Bangsa Inferior: Jakarta. Retrieved from

http://www.tempo.co/read/news/2014/02/26/079557683/Dirjen-Dikti-Suka-Menjipl ak-Tanda-Bangsa-Inferior.

Aryani, F. (2014). Studi tentang faktor-faktor penyebab perilaku plagiat mahasiswa UNM. Forum IImiah dan Seminar Internasional Forum FIP-JIP Se-Indonesia.

Retrieved from https://scholar.google.com.au/scholar?hl=en\&q=Studi+tentang+faktor-faktor+pen yebab+perilaku++plagiat++mahasiswa+UNM\&btnG=\&as_sdt=1\%2C5\&as_sdtp=

Bennett, K. K., Behrendt, L. S., and Boothby, J. L. (2011). Instructor Perceptions of Plagiarism Are We Finding Common Ground? Teaching of Psychology, 38(1), 29-35.

Fraser, R. (2014). Collaboration, Collusion and Plagiarism in Computer Science Coursework. Informatics in Education - An International Journal, 13(2), 179-195.

Halupa, C., \& Bolliger, D. U. (2013). Faculty perceptions of student self-plagiarism: an exploratory multi-university study. Journal of Academic Ethics, 11(4), 297-310.

Hu, G., \& Lei, J. (2012). Investigating Chinese university students' knowledge of and attitudes toward plagiarism from an integrated perspective. Language Learning, 62(3), 813-850.

Jiang, H., Emmerton, L., \& McKauge, L. (2013). Academic integrity and plagiarism: a review of the influences and risk situations for health students. Higher Education Research \& Development, 32(3), 369-380.

Kirsch, B. A., \& Bradley, L. (2012). Distance education and plagiarism prevention at the University of South Carolina Upstate. Journal of Library \& Information Services in Distance Learning, 6(2), 79-99.

Kutieleh, S., \& Adiningrum, T. S. (2011). How different are we? Understanding and managing plagiarism between East and West. Journal of Academic Language and Learning, 5(2), A88-A98.

Larsson, K., \& Hansson, H. (2013). Anti-plagiarism strategies: How to manage it with quality in large-scale thesis productions. International Journal for Educational Integrity, 9(2).

McGowan, U. (2008). International students: A conceptual framework for dealing with unintentional plagiarism. Student plagiarism in an online world: Problems and solutions, 92-107. 
Online Etymology Dictionary. (2015). Plagiarism, viewed 3 August 2015, $<$ http://www.etymonline.com/index.php?allowed_in_frame=0\&search=plagiarism \&searchmode $=$ none $>$.

Park, C. (2003). In other people's words: plagiarism by university students-literature and lessons. Assessment \& Evaluation in Higher Education, 28(5), 471-488.

Pudjiastuti, E. (2012). Hubungan self efficacy dengan perilaku mencotek mahasiswa psikologi. MIMBAR, 28(1), 103-112.

Risquez, A., O'Dwyer, M., \& Ledwith, A. (2013). 'Thou shalt not plagiarise': from self-reported views to recognition and avoidance of plagiarism. Assessment \& Evaluation in Higher Education, 38(1), 34-43.

Soendjoto, M. A. (2013). Plagiarisme, Kesalahan berbahasa tulis, dan penanggulangannya. Retrieved from http://www.dikti.go.id/id/2013/02/25/plagiarisme-kesalahan-berbahasa-tulis-dan-p enanggulangannya.

Sujarwo, Sugianto, Astuti, B., Eliasa, E. I., Tjictasari, F., Ratri, N. B., Mayasari, D. (2012). Identifikasi Bentuk Plagiat Pada Skripsi Mahasiswa Fakultas IImu Pendidikan Universitas Negeri Yogyakarta. Universitas Negeri Yogyakarta, Yogyakarta.

Sutherland-Smith, W. (2010). Retribution, deterrence and reform: the dilemmas of plagiarism management in universities. Journal of Higher Education Policy and Management, 32(1), 5-16.

Yeo, S. (2007). First year university science and engineering students' understanding of plagiarism. High Education Research \& Development, 26(2), 199-216. 